Ann. Zootech., I978, 27 (3), 335-346.

\title{
Responses of dairy ewes before and after parturition to different nutritional regimes during pregnancy
}

\section{II. - Energy intake, body-weight changes during lactation and milk production}

\author{
D. STERN, J. H. ADLER (*), H. TAGARI (**) and E. EYAI, \\ Institute of Animal Scicnce, Agricultural Research Organization, \\ The Volcani Center, Bet Dagan, Israel \\ (*) Dept. of Physiology, Hadassah-Hebrew University Medical School, Jerusalem, Israel \\ (**) Dept. of Animal Sciences, Faculty of Agriculture, \\ The Hebrew University of Jerusalem, Rehovot, Israel
}

\section{Summary}

Some effects of nutritional levels during pregnancy on subsequent lactation were studied in dairy ewes. Three basic (maintenance) rations and three steaming-up levels were compared in a factorial experiment. All ewes were fed $0.4 \mathrm{~kg}$ of hay daily and pellets ad libitum. Ewes entering late pregnancy in heavy body condition due to a high basic ration consumed $2 \mathrm{I}$ p. Ioo less feed in early lactation than those that had received the lower rations. Reduced appetite was more marked in single- than in twin-bearing ewes.

Steaming-up levels did not have any effect on ad lib. feed consumption during lactation. Twin-bearing ewes consumed, on the average, $9.6 \mathrm{p}$. 100 more feed than single-bearing ones.

There was a negative correlation between body weight change during lactation and weight change during pregnancy.

Overfatness of ewes was followed by low milk yields. In ewes which had been on constant steaming-up levels during the last two months of pregnancy, milk production was significantly higher in twin- than with single-bearing ewes. There was no such difference in the ewes whose feed allowance during pregnancy had been gradually raised according to the free fatty acid concentration in their blood plasma.

There was no correlation between feed intake and body weight change during lactation on the one hand, and body weight change and milk production on the other hand. There were highly significant correlations between feed intake and milk yield.

Fat percentage in milk was not affected by feeding level during pregnancy. Average fat level was $6.7 \div 0.2 \mathrm{p}$. I 100 and $7.5 \div 0.2 \mathrm{p}$. Ioo in the milk of twin- and single-beating ewes, respectively.

\section{Introduction}

The effect of nutrition during gestation on the embryo's development and on the well-being of the ewe and of the newborn lamb has been studied in detail and described by numerous authors (e.g., REID, I963; GORDON and TRIBE, I95I; 
DONALD and RUSSEL, I970; STERN et al., I978). Some recent work indicates that feeding levels during pregnancy may also affect the subsequent lactation of the ewe (BUTTERWORTH and BloRe, I969; GARDNER and Hogue, I963; PEART, I967; TrEACHER, I970, I97I). Furthermore, there seems to exist an interaction between body condition (degree of fatness) of the ewe during different stages of gestation and the level of extra feed allowance during late pregnancy commonly referred to as "steaming-up" (PEART, I968, I970; and unpublished results of our laboratory). All published literature on this subject deals with milk production as a major factor affecting lamb production. To the best of our knowledge, there are no reports on dairy sheep. The present communication is part of a study to clarify the interaction of body condition and feeding level during the period between conception and the subsequent parturition, in sheep which are kept for high levels of production of both lambs and milk. A detailed description of the experiment which was carried out, and of the effects of the various feeding regimes on lamb production, is included in a previous communication (STER. et al., I978).

\section{Materials and methods}

\section{General}

Forty-two Awassi and Assaf ewes were block randomized into nine treatment groups $(3 \times 3$ factorial). The experimental treatments included three sequences of basic diets throughout pregnancy: I) flushing and high maintenance (fh); 2) flushing and low maintenance ( $\mathrm{fn})$; 3 ) no flushing and low maintenance (nn); and three levels of steaming-up: high $(\mathrm{H})$, low $(\mathrm{L})$, and adjusted according to blood plasma free fatty acid concentration (A). Each ewe was kept in the experiment 45 days post-partum. The experiment was described in detail by STERN et al. (I 978). Only details pertaining specifically to the lactation period will be described below.

\section{Feeds and feeding}

Ewes were maintained in individual pens. From parturition onwards each ewe received $0.4 \mathrm{~kg}$ hay daily and concentrate pellets containing $14.5 \mathrm{p}$. Ioo fiber and $5.5 \mathrm{p}$. Ioo crude protein ad libitum in individual self-feeders. Self-feeder balance was done every week and from this average, daily consumption was calculated. Feed composition was given by STERN et al. (1978).

\section{Weighing of eies}

Ewes were weighed on the morning of the third day post-partum and at fortnightly intervals thereafter.

\section{Suckling of lambs and milk recording}

Each ewe suckled only one lamb. Litter mates from twin or triplet births were taken away $48 \mathrm{~h}$ post-partum for artificial rearing. From the fourth day on, the remaining lamb was put with its mother for 15 minutes only after the morning 
and evening milkings to suck whatever residual milk there was in the udder. Milk yields were recorded every fortnight. On recording days lambs were weighed before and after suckling to estimate the suckling yield (SuY); total yield (TY) was estimated by adding SuY to the milked or dairy yield (DY). See MoraG et al. (1973) for detailed definitions of milk fractions. Percent dry matter (DM) in milk was determined by drying in an oven at $105^{\circ} \mathrm{C}$; percent fat by the Gerber method; and percent solids not fat (SNF) by subtracting fat percent from DM. Aliquots of the morning and evening milkings were combined for analysis to represent the composition of the DY.

Determinations of the composition of the suckled milk were done twice during the 45-day suckling period for each ewe. To obtain the residual milk, five international units of oxytocin were injected into the jugular vein immediately after milking. Residual milk was then milked, weighed, and sampled for analysis. To calculate the energy value of milk, it was assumed that each gram of fat was equivalent to 9.4 and each gram of SNF to 4.9 calories. Combined fat or SNF vields of the dairy plus the suckled milk were used to calculate the percent of these fractions of the total milk yield and thus the total milk energy.

\section{Results}

\section{Feed intake}

Prepartum nutritional level affected feed intake during lactation (Table I). The reduction in appetite as a result of the high basic level (fh) (ewes entering late pregnancy in fat condition) was particularly marked. Loss of appetite was more severe in single-bearing than in twin-bearing ewes. The effect of the " steamingup " regimes on feed intake during lactation was small and statistically not significant.

The fact that in twin-bearing ewes intake was greater (by an average of $9.6 \mathrm{p}$. Ioo) than in single-bearing ewes is noteworthy. This difference between the ewes of the two birth types was smallest in the adjusted steaming-up groups (A). All these differences persisted over the first 6 weeks of lactation, when intake increased continuously in all the groups.

\section{Body weight changes}

There was a noticeable difference at mating and in early pregnancy between body weights of twin- and single-bearing ewes. The former were heavier than the latter (see STERN et al., I978). This difference disappeared almost completely during the last two months of pregnancy.

At lambing, twin-bearing ewes (who either lost more or gained less weight) were heavier by only $3 \mathrm{p}$. Ioo, on the average, than single-bearing ewes.

On the other hand, significant differences in weight remained between ewes which had been on different basic rations. The same holds true for ewes on different steaming-up levels.

During the first 6 weeks of lactation (when ewes were fed ad libitum) there was a negative relationship between progressing body weight changes during this 


\section{TABLE I}

Average daily intake of metabolizable energy $(M J)$ per ewe fed ad libitum in the first six weeks of lactation, for ewes on different feeding vegimes during pregnancy (number of ewes is given in parentheses)

Consommation journalière d'énergie métabolisable par brebis nourrie ad libitum pendant les 6 premières semaines de lactation chez les brebis ayant recu différentes rations pendant la gestation (le nombre de brebis est indiqué entre parenthèses)

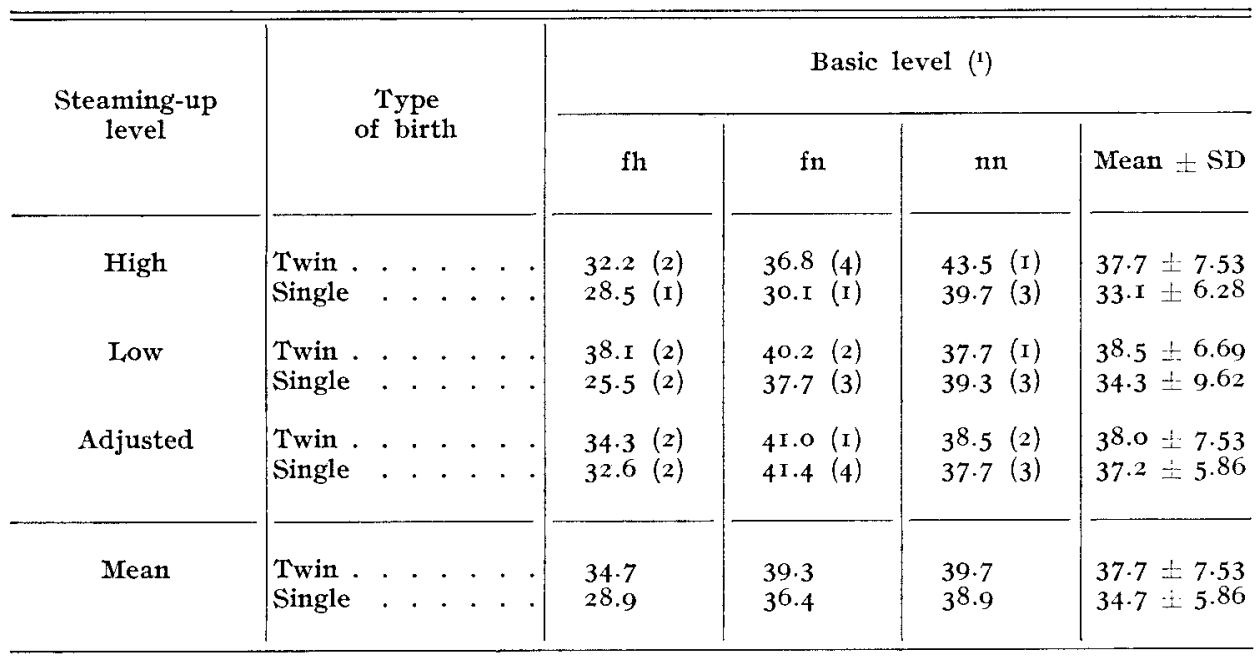

(1) See Material and Methods.

Analysis of variance:

Between basic levels: $\mathbf{P}<0.05$.

Between steaming-up levels: $\mathbf{P}<$ o. Io.

Between types of birth: $\mathrm{P}<0.0 \mathrm{r}$.

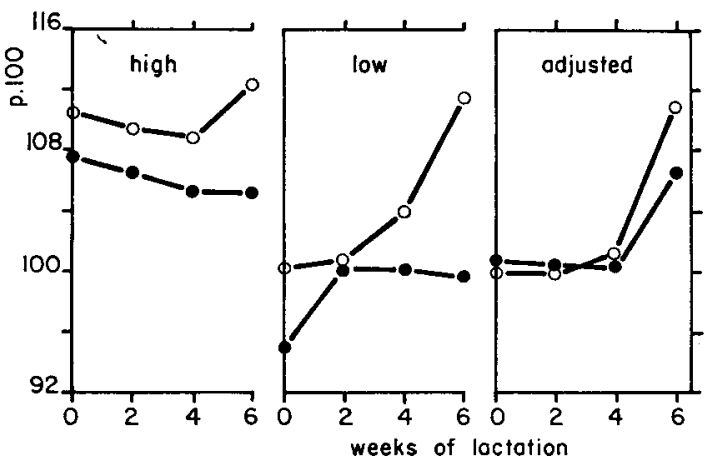

FIG. I. - Changes in body weight in eavly lactation relative to weight at mating (Ioo p. Ioo) in ewes on different steaming-up regimes in late pregnancy (high, low or adjusted) according to blood FFA concentration.

$$
\begin{array}{lc}
\text { - twinners } & \text { O singlers } \\
\text { jumeaux } & \text { I agneau }
\end{array}
$$

Variations pondérales pendant le début de la lactation sur la base du poids lors de l'insémination ( 100 p. IOO) de la brebis ayant reçu différents régimes de "préparation à la mise-bas "pendant la fin de la gestation (régimes abondant, pauvre, ou bien ajusté) selon la concentration du sang en acides gras libres. 
period and those associated with advancing gestation. The correlation coefficients $(r)$ were $-0.727(\mathrm{P}<0 . \mathrm{or})$ for ewes fed the constant steaming-up regimes $(\mathrm{H}$ and L) and - 0.369 (NS) for the adjusted group (A). Fig. I shows the relative body weight changes of ewes during the first six weeks of lactation (weight at mating $=$ I00 $\mathrm{p}$. I00). The following facts were evident:

a) The smallest change from mating to lambing occurred in the adjusted group. Differences between twin- and single-bearing ewes were also smallest in this group.

b) 'There was a marked difference in the course of weight change during early lactation between twin- and single-bearing ewes. Twinners lost weight or gained only a little; singlers lost little or gained at a noticeably greater rate. There was no correlation between body weight changes and feed intake.

\section{Milk yields}

Average daily milk yields in the first six weeks of lactation for sheep which had received different rations during pregnancy are shown in Table 2.

It seems evident that overfattening during gestation (basic level fh) led to reduced milk yield, especially in single-bearing ewes. Also, the milk yield of twin-

TABLE 2

Average daily milk yields $(k g)$ for the first six weeks of lactation,

for ewes fed on different feeding regimes during pregnancy (number of ewes as in Table $I$ )

Production journalière de lait $(k g)$ pendant les 6 premières semaines de lactation,

de brebis ayant reç différentes rations pendant la gestation (nombre de brebis : cf. tabl. I)

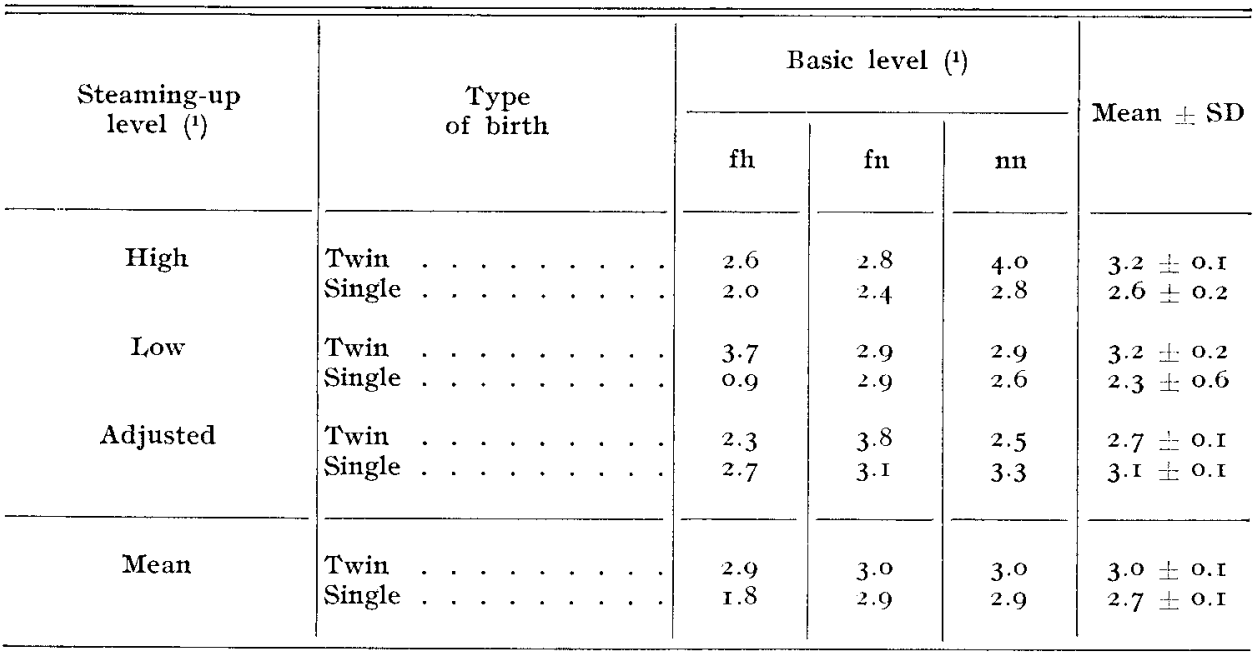

(1) See Materials and Methods.

Analysis of variance:

Between basic levels: $\mathbf{P}<0.05$.

Between steaming-up levels: NS.

Between types of birth: $P<0.05$.

Interaction between basic ration and type of birth: $P<0.05$.

Interaction between steaming-up and type of birth: $P<0.01$. 
bearing ewes on constant " steaming-up " regimes ( $\mathrm{H}$ and $\mathrm{L}$ ) was higher than that of singles. Furthermore, ewes on the adjusted regime showed no such difference, and there was even a tendency toward a higher milk yield in single-bearing ewes.

Figure 2 shows that yields increased until the 4 th week of lactation and then stabilized or began to decrease.

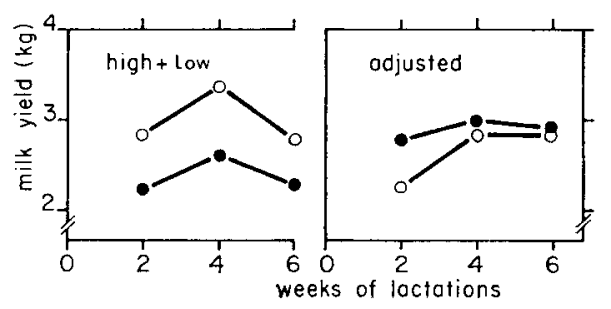

FIG. 2. - Daily milk yields in the first 6 weeks of lactation, in ewes fed different steaming up rations during late pregnancy.

$$
\begin{array}{ll}
\text { twinners } & \text { singlers } \\
\text { jumeaux } & \text { I seul agneau }
\end{array}
$$

Production journalière de lait pendant les 6 premières semaines de lactation de brebis ayant rę̧u différentes rations de "préparation à la mise-bas "pendant la fin de la gestation.

In ewes on constant steaming-up regimes, the difference between twinners and singlers was maintained throughout the first 6 weeks of lactation. In the adjusted steaming-up feeding (A), a tendency was found for twin-bearers' milk yield to rise more steeply, but by the 6th week both groups had equal yields.

No correlation was found between body weight changes during lactation and milk yield. The correlations between milk yield and feed intake were significant at each of the three points that were tested during the first 6 weeks of lactation. The correlation coefficients are shown in Table 3.

\section{TABLE 3}

Corvelation coefficient $(v)$ between milk yield and feed intake in the first six weeks of lactation Coefficient de corrélation entre la production de lait et la consommation de fourrage pendant les six premières semaines de lactation

\begin{tabular}{|c|c|c|c|c|}
\hline \multirow{2}{*}{$\begin{array}{l}\text { Steaming-up } \\
\text { levels }\end{array}$} & \multirow{2}{*}{$\begin{array}{l}\text { Number } \\
\text { of ewes }\end{array}$} & \multicolumn{3}{|c|}{ Weeks of lactation } \\
\hline & & 2 & 4 & 6 \\
\hline $\begin{array}{l}\mathrm{H} \text { et } \mathrm{L} . \\
\mathrm{A}\end{array}$ & $\begin{array}{l}25 \\
14\end{array}$ & $\begin{array}{l}0.840 \quad(* * *) \\
0.228 \text { NS }\end{array}$ & $\begin{array}{l}0.806\left(^{* *}\right) \\
\left.0.631{ }^{*}\right)\end{array}$ & $\begin{array}{l}0.594{ }^{(*)} \\
0.826(* *)\end{array}$ \\
\hline
\end{tabular}

NS: Non-significant.

$* \mathrm{P}<0.05 ; * * \mathrm{P}<0.01 ; * * * \mathrm{P}<0.001$. 


\section{Milk fat percentages}

The effect of prepartum nutritional levels on the percentage of milkfat was small (Table 4), yet differences found between various steaming-up regimes were significant $(\mathrm{P}<0.05)$. It appears that low $(\mathrm{L})$ level, especially in the case of fat ewes (basic level fh), led to a relatively low percentage of milk fat.

\section{TABLE 4}

Average fat percentage in milk during the first six weeks of lactation of ewes fed different levels during gestation and ad libitum during lactation

(number of ewes as in Table 1 )

Pourcentage moyen de matières grasses, pendant les 6 premières semaines de lactation, dans le lait de brebis nourries avec des rations différentes pendant la gestation

et ad libitum pendant la lactation

(nombre de brebis : cf. tabl. I)

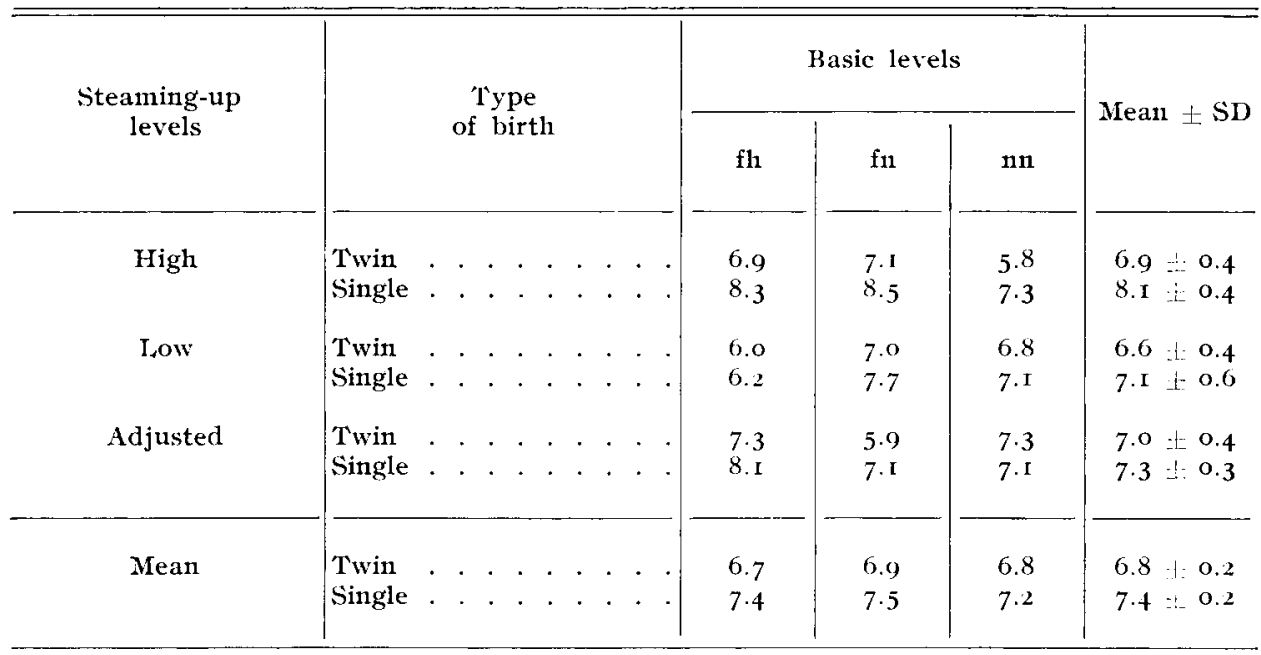

Analysis of variance:

Between basic levels: $\mathbf{P}<0$. Io.

Between steaming-up levels: $P<0.05$.

Between types of birth: $\mathbf{P}<0.05$.

Interaction between basic level and steaming-up level: $\mathbf{P}<0.05$.

The most prominent differences were again observed between twin- and singlebearing ewes, with the fat content of the latter's milk being consistently higher. It is interesting to note that this state exists not only in the constant " steamingup " regimes (H, L), where the milk yield of single-bearing ewes was lower, but also in ewes on the adjusted regime (A), where the milk yield of single-bearing ewes was high.

In figure 3 , it can be seen that the differences between single and twin-bearing ewes were maintained during the first 6 weeks of lac tation. Within each regime, there was an inverse relation of milk yield to fat percentage. 


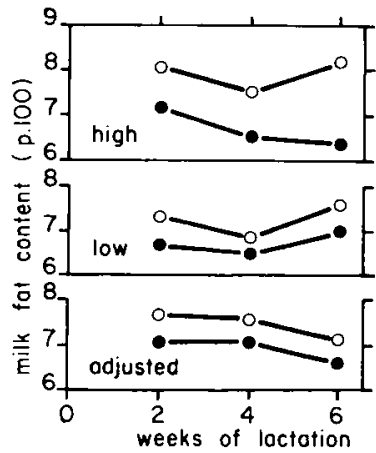

FIG. 3. - Fat percentages in milk of ewes fed various steaming-up rations in late pregnancy.

- twinners $O$ singlers jumeaux I seul agneau

Pourcentage de matières grasses du lait de brebis ayant reçu différentes rations de "priparation à la mise-bas" pendant la fin de la gestation.

\section{Total milk energy}

The higher level of milk fat in single-bearing ewes was not enough to make up for their milk yield in comparison with the twin-bearing ewes on constant steamingup regimes $H$ and $L$, when milk yield was expressed as energy (Table 5). In the

TABI,E 5

Average daity milk energy yields $(M J)$ during the first six weeks of lactation (number of ewes as in Table I)

Production journalière d'ćnergie dans le lait pendant les six premières semaines de lactation (nombre de brebis : cf. tabl. I)

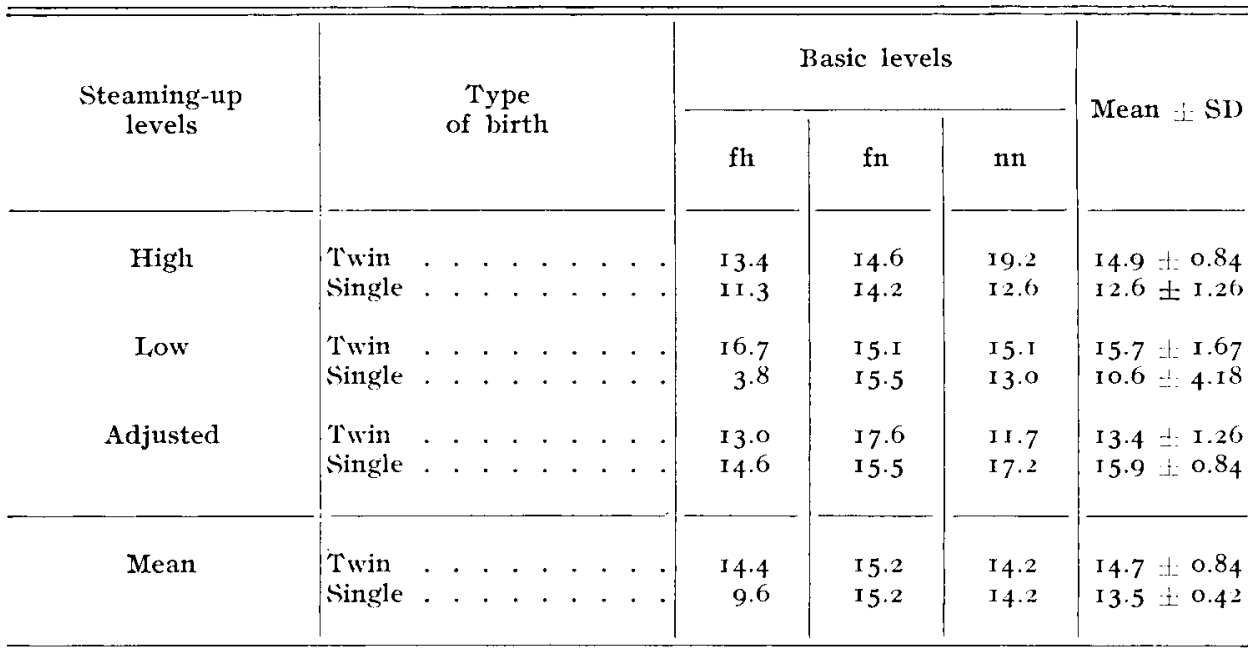

Analysis of variance:

Between basic levels: I' $<0.10$.

Between steaming-up levels: $P<0.05$.

Between types of birth: $P<0.05$.

Interaction between basic and steaming-up levels: $\mathbf{P}<0.05$. 
adjusted steaming-up regime (A), there was a high percent of milk fat in singlebearing ewes along with a higher milk yield, compared with twin-bearing ewes. Therefore, the differences between ewes of the two birth types in this regime are even greater when expressed in energy than when expressed in milk yield.

The differences between energy yield of ewes on the various " steaming-up " regimes were found to be significant (not so for the milk yield expressed in $\mathrm{kg}$ ). The differences arise mainly from the single-bearing ewes. Single-bearing ewes which were on the adjusted feeding before lambing produced both more SNF and more fat than those with a constant steaming-up $(P<0.05)$. In twin-bearing ewes an opposite trend was noted, but differences were small and statistically not significant.

\section{Discussion}

\section{Effect of prepartum nutrition on feed intake during lactation}

The " steaming-up " regimes had only a small effect on feed intake during lactation. Actually, a slightly higher intake compared with that of other steamingup groups was noted in single-bearing ewes in the adjusted (A) feeding regime alone. Even there, the positive effect was limited to sheep on the high basic levels (fh, $\mathrm{fn}$ ). Sheep entering the steaming-up period in a fat condition suffered from inappetance towards the end of gestation (STERN et al., I978) and it seems that this effect was carried over into the lactation.

Contradictory results exist in the literature on this subject. TREACHER (I970) found that the nutritional level in late pregnancy had no influence on feed intake during lactation. PEART (1967), on the other hand, did find such an effect. It is worth noting that in PEART's work the ewes' ration in late pregnancy was adjusted according to FFA concentration in the blood. It may be suggested that increased feeding at a constant level during the late months of pregnancy is apt to increase appetite in early lactation, when given to lean ewes. For an average population, a gradually increased diet may be advantageous. Overfattening would probably induce inappetance.

\section{Relationship between feeding levels, body weight changes and milk yield}

High correlation coefficients were found between feed intake and milk yield, as in other studies (PEART, I967; Forbes, 1969; TREACHER, 1970). However, there was no correlation between feed intake and body weight change during lactation, nor between body weight change and milk yield. Feed intake was in fluenced to a certain degree by the ewes' body condition at the end of pregnancy. Thus, lean ewes consumed more than those in heavy condition under the ad libitum feeding in this study. They consumed well in excess of their maintenance plus lactation requirements. This resulted in an inverse relation between rate of body weight change during gestation and that during lactation. An identical result was recorded by TREACHER (I970). The maintenance levels and steaming-up levels alike were found to have virtually no effect on feed intake and milk yield in the subsequent lactation of twin-bearing ewes. On the other hand, they clearly affected single bearers, which were severely affected by the high maintenance level 
(obesity) but particularly benefited from the FFA adjusted feeding (A). It is noteworthy that the latter feeding regime also produced the heaviest lambs.

Twin-bearing ewes consumed more food post-partum and put on more weight than singlers. In the constant (both high and low) steaming-up regimes, twinners produced more milk as well. This can perhaps be explained by the fact that when on a constant pre-partum nutritional level, twin-bearing ewes come much closer to a state of energy deficiency than do the single-bearing ewes, by the end of gestation. PEART (I 968) showed that lean ewes (in the present case, twin-bearers) utilized their food more efficiently for the production of milk than did fat ewes. It is, however, possible that the very hormonal differences responsible for different ovulation rates at mating also affect milk yield. The literature supports the conjecture that these same hormones act on fertility and milk production (see, for example, HUNTER, I968). The difference in feed intake cannot be related to body weight differences, since the latter disappeared almost completely between mating and lambing. The twin-bearing ewes were on the average $3 \mathrm{p}$. Ioo heavier than single bearers (not significant). However, the average difference in feed intake was of the order of Io p. Ioo $(p<0.01)$.

The only comparisons in the literature between the type of birth and milk yields in dairy sheep were those of Goo' (r966, r974). He found differences closely resembling those described herein, although of a much smaller magnitude.

Many researchers found a high level of milk production in twin-bearing ewes (WALIACE, I948; BARNICOAT, LOGAN and GRANT, I949;AI,EXANDER and DAVIES, I959; HADJIPIERIS and Holmes, I966; PEAR'T, I967), but none of these studies are comparable to ours, since they dealt with ewes which bore and also suckled twins, and were not milked at all. In this study, twin-bearing ewes suckled only one lamb and the suckling consisted only of milk left over after milking. For the adjusted feeding groups (A) the difference in body condition and energy balance in late pregnancy between twin- and single-bearing ewes was very small. However, also here, trends in feed intake and body weight changes resembled those in other regimes. On the other hand, the milk yield of single-bearing ewes was higher than or comparable with that of twinners. This indicates primarily that the adjusted feeding (A) led to higher efficiency not only in lamb production (STERN et al., I978), but also in milk production. In addition, it seems that twin-bearers, for the same reasons, perhaps, that they produced relatively small lambs (STERN et al., I978) were also unable to attain high levels of milk production.

Under the present conditions, when initial feeding was ad libitum, there was no benefit from the reserves built up in the ewe's body from the high steaming-up regime $(\mathrm{H})$. However, the situation may be different in the case of a rationed diet, where a temporary energy deficit is liable to appear, at least in early lactation. Support for the hypothesis that ewes may benefit from a build-up of body reserves in pregnancy may be found in the reports of PEART (I970) and TREACHER (I97I), who found that ewes fed more in late pregnancy were able to maintain a higher milk yield over a short period when the feeding during lactation was deficient. These differences in the lactation response to different pre-partum feeding levels may explain at least some of the contradictions found in the literature on this subject.

That fat percentage falls as milk yield rises, particularly on a concentrated ration, is known from the literature on dairy cows (STORREY, I970). The nutrition in late pregnancy (steaming-up levels) seems to have affected single-bearing ewes, in agreement with SPRAY (I950) for non-ruminating animals, and with TREACHER (I97I) for sheep. These investigators determined that milk-producing females can draw energy from depots formed in the body late in gestation. 
Single-bearing ewes of the adjusted regime had a higher fat percentage in their milk despite the fact that in this treatment they also produced more milk. When this is added to other evidence, it leads us to the conclusion that the pattern at which a ration is being increased during gestation may affect the partition of metabolites in the animal's body both before and after parturition. Differences in SNF concentration were smaller, but they showed similar trends.

Accepté pour publication en iévier 1978 .

\section{Acknowledgements}

This study has been supported by a grant from the Israeli Sheep Breeders Association. We also wish to express our gratitude to $\mathrm{Mr}$. A. LAw and the team of workers caring for the experimental flock at Newe Ya'ar for the good care of the animals, and to Mr. Y. AsT, Mrs. J. VERTESH-LEVY, Mr. S. BJ:Y-YONAH and Mr. I. 'TALBY for technical assistance.

\section{Résumé}

Réponses de brebis laitières avant et après l'agnelage à différents niveaux d'apports alimentaires pendant la gestation II. - Consommation d'énergie et variation de poids pendant la lactation, et production laitière

On a étudié certaines répercussions des niveaux d'apports alimentaires distribués pendant la gestation sur le déroulement de la lactation suivante chez des brebis laitières. Trois séquences d'apports alimentaires de base ( $\mathrm{fh}, \mathrm{fn}$ et $\mathrm{nn}$ ) et trois niveaux de supplémentation à la fin de la gestation (H, I, et A) ont été comparés dans une expérience factorielle. Toutes les brebis ont reçu chaque jour $0,4 \mathrm{~kg}$ de foin et de l'aliment concentré aggloméré ad libitum.

Les brebis grasses à l'approche des deux derniers mois de gestation (séquence fh) ont moins consommé au début de la lactation ( $-2 \mathrm{I}$ p. roo) que les brebis plus restreintes avant la fin de la gestation (séquences fn et $\mathrm{nn}$ ). Cette diminution des quantités ingérées était plus marquée chez les brebis ayant mis bas des agneaux simples que chez celles ayant mis bas des jumeaux.

Les niveaux de supplémentation à la fin de la gestation n'affectent pas les quantités ingérées au début de la lactation. Les brebis mères de jumeaux consomment 9,6 p. roo de plus que les brebis mères d'un unique agneau.

On observe une corrélation négative entre la variation de poids pendant la lactation et celle pendant la gestation.

Un état d'engraissement excessif des brebis se traduit par une faible production laitière ultérieure. Lorsque la supplémentation était constante pendant la fin de la gestation (niveaux $H$ et $L$ ), la production de lait des mères de jumeaux était significativement supérieure à celles des mères d'un seul agneau. Cette différence n'existait pas pour les brebis dont la supplémentation était progressivement augmentée en fonction de la teneur plasmatique en acides gras libres (niveau A).

Il n'existait pas de liaison entre les quantités ingérées et les variations de poids pendant la lactation d'une part, et entre les variations de poids et la production laitière d'autre part. Par contre, une corrélation hautement significative existait entre les quantités ingérées et la production laitière.

Le taux de matières grasses du lait n'a pas été affecté par les niveaux d'apports alimentaires distribués pendant la gestation. Il a été en moyenne de $6,7 \div 0,2$ p. Ioo et $7,5: 0,2$ p. I oo pour les mères de jumeaux et d'un seul agneau respectivenent.

\section{References}

Alexander G., Davifs H. L., I959. The relationship of mitk production to number of lambs born or suckled. Aust. J. agric. Res., 10, 720-724.

Barnicoat C. R., Logan A. G., Grant A. I., 1949. Milk secretion studie; with New Zealand Romney ewes. I. agric. Sci. Camb., 39, 44-55. 
BUTTERWORTH M. H. and BLORE T. W. D., 1969. The lactation of Persian Blackhead ewes and the growth of lambs. The effect of three different nutritional regimes during gestation on subsequent growth. J. agric. Sci. Camb., 73, 133-137.

DoNAid H. P., RUSSELI, W. S., I970. The relationship between liveweight of ewe at mating and weight of new born lamb. Anim. Prod., 12, 273-280.

FORBES J. M., I969. A note on the voluntary feed intake of lactating ewes, their milk yield and the growth rate of their lambs. Anim. Prod., 11, 263-266.

GARDNER R. W., HOGLE D. E., 1963. Studies of the TDN requirements of pregnant and lactating ewes. J. Anim. Sci, 22, 410.

GOOT H., 1966. Studies on the native Awassi sheep and its crosses with exotic East-Friesian milk sheep. National and University Institute of Agriculture, Israel, Bulletin $\mathrm{n}^{\circ} 124$ (Hebrew, with English summary).

Goot H., 1974. Milk yield and lactation length of single- and twinbearing Assaf dairy ewes. Israel Journal of agricultural Research, 23, I55-158.

GoRdon J. G., TRIBE D. E., i95I. The self-selection of diet by pregnant ewes. $J$. agric. Sci., 41, 187 -190.

HADJIPIFRIS G., Holmes W., 1966. Studies on feed intake and feed utilization by sheep. I. The voluntary feed intake of dry, pregnant and lactating ewes. J. agric. Sci. Camb., 66, 21 7-223.

Huxter G. L., I 968 . Increasing the frequency of pregnancy in sheep. I. Some factors affecting rebreeding during the postpartum period. Anim. Breed. Abstr., 36, 533-553 (a review).

Morag M., Sagi R., Eyal E. and Folman Y., I973. The definition of milk yield and milk fractions in lactating animals. J. agric. Sci. Camb., 81, 361-363.

PEART J. N., 1967 . The effect of different levels of nutrition during late pregnancy on the subsequent milk production of Blackface ewes and on the growth of their lambs. J. agric. Sci. Camb., $68,365-37 \mathrm{I}$.

PEART J. N., I 968 . Some effects of liveweight and body condition on the milk production of Blackface ewes. J. agric. Sci. Camb., 70, 331-338.

PFART J. N., 1970. The influence of liveweight and body condition on the subsequent milk production of Blackface ewes following a period of undernourishment in early lactation. $J$. agric. Sci. Camb., 75, 459-469.

REID R. L., I963. The nutritional physiology of the pregnant ewe. J. Atst. Inst. agric. Sci., 29, $215^{-113}$.

SPRAY C. MI, 1950. A study of some aspects of reproduction by means of chemical analysis. Bir. J. Nutr., 4, 354-360.

Stern D., Adler J. H., 'TAGari H., Eyal E., 1978. Responses of dairy ewes before and after parturition to different nutritional regimes during pregnancy. I. Ewe Body weight, uterine contents, and lamb birth weight. Ann. Zootech., 27, 31 7-333.

STORREY J. E., 1970. Ruminant metabolism in relation to the synthesis and secretion of milk fat (a review). J. Dairy Res., 37, 189-194.

TREACHER T. T., I97o. Effect of nutrition in late pregnancy on subsequent milk production in ewes. Anim. Prod., 12, 23-36.

TREACHER T. T., 1971. Effect of nutrition in pregnancy and in lactation on milk yield in ewes. Anim. Prod., 13, 493-501.

WALLACE L. R., I 948 . The growth of lambs before and after birth in relation to the level of nutrition. J. agric. Sci. Camb., 38, 243-302. 